\title{
CLIMATIC RISK FOR POTATO LATE BLIGHT IN THE ANDES REGION OF VENEZUELA
}

\author{
Beatriz Ibet Lozada Garcia ${ }^{1}$; Paulo Cesar Sentelhas²*; Luciano Roberto Tapia ${ }^{3}$; Gerd \\ Sparovek $^{4}$ \\ ${ }_{2}^{I}$ Instituto Nacional de Investigaciones Agrícolas (INIA), Bramón, Táchira - Venezuela. \\ ${ }_{3}^{2}$ USP/ESALQ - Depto. de Ciências Exatas, C.P. 09 - 13418-900 - Piracicaba, SP - Brasil. \\ ${ }^{3}$ USP/CIAGRI - C.P. 09 - 13418-900 - Piracicaba, SP - Brasil. \\ USP/ESALQ - Depto. de Ciência do Solo. \\ *Corresponding author 〈pcsentel@esalq.usp.br>
}

ABSTRACT: Potato is an important crop for Venezuelan agriculture. However, its production is highly affected by late blight (Phytophtora infestans), since weather is commonly favorable for this disease. The aim of this study was to determine the sowing dates of low climatic risk for potato late blight in the Andes region of Venezuela, with an agrometeorological disease model and geographical information system (GIS) tools. The disease model used in this study was developed by Hyre (1954) which requires daily rainfall and temperature data which were obtained from 106 weather stations, located at the States of Mérida, Táchira, and Trujillo, for a period of 31 years. Hyre's model was applied for all stations obtainig the following variables: number of disease favorable days (DFD); number of periods with ten consecutive favorable days, named disease occurrence $(\mathrm{O})$; and number of sprays required for disease control (S). These variables were used to calculate the Maximum Risk Index (MRI) and the Probable Risk Index (PRI). The interpolation of these indexes was used to generate maps of climatic risk for each sowing date. MRI and PRI maps showed that the highest climatic risk for potato late blight occurrence was during the rainy season, from May to July, decreasing during dry and mid seasons. However, high disease risk variability was observed for all seasons. The maps generated by coupling an agrometeorological disease model and GIS also show that in great part of potato areas of Andes region the number of sprays could be reduced, but more investigations about that must be carried out.

Key words: Phytophtora infestans, Hyre's model, temperature, rainfall

\section{RISCO CLIMÁTICO PARA A OCORRÊNCIA DE REQUEIMA DA BATATA NA REGIÃO ANDINA DA VENEZUELA}

RESUMO: A batata é uma importante cultura para a agricultura venezuelana. Entretanto, sua produção é altamente afetada pela ocorrência da requeima (Phytophtora infestans), já que as condições climáticas são normalmente favoráveis para essa doença. O objetivo deste estudo foi determinar as datas de semeadura com os menores riscos climáticos para a ocorrência da requeima na região andina da Venezuela, considerando o uso de um modelo agrometeorológico de previsão da doença e um sistema de informação geográfica (GIS). O modelo de estimativa da doença utilizado foi o desenvolvido por Hyre (1954), o qual requer dados diários de chuva e temperatura. Esses dados foram obtidos de 106 estações meteorológicas, situadas nos estados de Mérida, Táchira e Trujillo, para períodos de 31 anos. O modelo de Hyre foi aplicado para todas as estações, obtendo-se as seguintes variáveis: número de dias favoráveis à doença (DFD); número de períodos com dez dias favoráveis consecutivos, denominado de ocorrência $(\mathrm{O})$; e número de pulverizações requeridas para o controle da doença $(\mathrm{S})$. Essas variáveis foram utilizadas para calcular o Índice de Máximo Risco (MRI) e o Índice de Risco Provável (PRI). A interpolação desses índices foi usada para gerar mapas de risco climático para cada época de semeadura. Os mapas de MRI e PRI mostraram que os maiores riscos para a proliferação da requeima da batata ocorre na estação chuvosa, de maio a julho, decrescendo durante as estações seca e de transição. Entretanto, alta variabilidade do risco para a doença foi observada em todas as épocas de semeadura. Os mapas gerados pela combinação do modelo agrometeorológico de previsão da doença e GIS também mostraram que em boa parte das áreas produtoras de batata na região andina da Venezuela a redução do número de pulverizações pode ser possível, no entanto há necessidade de novas pesquisas para se comprovar isso.

Palavras-chave: Phytophtora infestans, modelo de Hyre, temperatura, chuva 


\section{INTRODUCTION}

Potato (Solanum tuberosum L.) is one of the main crops of the Andes region of Venezuela, which is composed by the states of Táchira, Mérida, and Trujillo. The altitude of the areas where the potato crop is grown in this region is between 400 and 3,000 meters above sea level, where average temperatures range from 10 to $20^{\circ} \mathrm{C}$ and annual rainfalls from 1,000 to $1,800 \mathrm{~mm}$. However, according to Escalante \& Farrera (2004), these climatic conditions are also very favorable for potato late blight (causal agent Phytophtora infestans (Mont) de Bary), which is the main limitation for local potato production, causing losses up to $100 \%$ in some years (Garcia \& Garcia, 2004).

Control of potato late blight is done in several ways, combining cultural practices with regular fungicides application during the growing season (Garrett \& Dendy, 2001; Taylor et al., 2003; Lozada Garcia, 2005; Kirk et al., 2005). Even considering cultural practices as very important for potato production, chemical control is essential for this crop (Hijmans et al., 2000). A typical fungicide application schedule used by growers in Andes region of Venezuela is a 7-day spray interval, very similar as for other regions around the world. The excessive use of fungicides for potato production makes control very expensive and may cause environmental contamination, so more economical and environmentally sound control measures are needed (Kirk et al., 2005).

Several strategies have been developed and applied to reduce the amount of fungicide sprays for potato late blight control. Some of them are based on the combination of plant resistance, reduced rates and frequencies of fungicides applications (Kankwatsa et al., 2003; Kirk et al., 2005) and others on decision support systems (DSS), also known as disease warning systems, which take into account available information about crop, pathogen, fungicides, and mainly weather (historic and forecast) to determine when to spray.

The objective of the present study was to determine the sowing dates of low late blight risk for the potato crop in the Andes region of Venezuela, by the use of a GIS-linked weather-based disease model, to provide subsidies for planning rational disease control in the different growing seasons.

\section{MATERIAL AND METHODS}

\section{Location and weather data}

The region of this study comprises the states of Táchira, Mérida, and Trujillo, in the Andes region of Venezuela (Figure 1), with altitudes ranging from 0 to 5,000 meters. Because of the high variation of altitude, the climates of this region are diverse, including tropical savanna (Aw), tropical wet (Af), humid subtropical (Cf), subtropical steppe (BS), and highland $(\mathrm{H})$, according to Koeppen climate classification. Our study was based on daily weather data from 106 stations, belonging to Ministry of Environment and Natural Resources (MARN) of Venezuela, distributed in the three different states of the Andes region for a period of 31 years, from 1967 to 1997.

As few of the weather stations in this regions were able to provide a complete daily temperature dataset, climatological maximum and minimum daily temperatures were estimated by the regression method proposed by Lozada Garcia (2005), using the relationship among temperature and geographical coordinates (altitude, longitude and latitude), as follows:

$\mathrm{T}=\mathrm{a}+\mathrm{b}$ Altitude $+\mathrm{c}$ Longitude $+\mathrm{d}$ Latitude

where $\mathrm{T}$ is temperature $\left({ }^{\circ} \mathrm{C}\right)$ and $a, b, c$ and $d$ are the empirical coefficients of the multiple linear regression, determined with data from 17 weather stations in the Andes region.

Missing data observed in the rainfall series of the 106 stations (17\% of the total days) were filled in using the Closest Station method, based in a cluster analysis approach, proposed by Lozada Garcia et al. (2006).

\section{Disease forecast model}

Considering the limitations of weather data in the Andes region of Venezuela, the disease model used

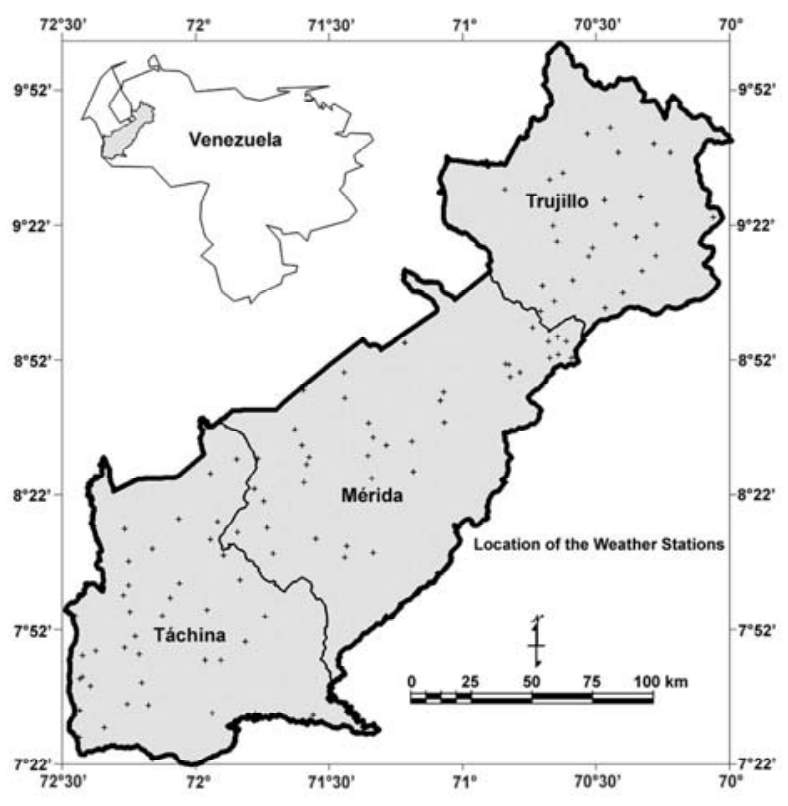

Figure 1 - Location of the weather stations, distributed in the states of Táchira, Mérida and Trujillo, Venezuela. 
in this study was that one developed by Hyre (1954), which is the simplest among the available models. This model has been extensively evaluated and implemented by growers in the northeastern United States (California PestCast, 2007). Hyre (1954)'s model is just based on daily rainfall and maximum and minimum temperatures. It forecasts the outbreak of potato late blight 714 days after the occurrence of ten consecutive late blight favorable days. Days are considered late blight favorable when the 5-day average temperature $\left(\mathrm{T}_{5 \mathrm{~d}}\right)$ is below $25.5^{\circ} \mathrm{C}$ and the total rainfall for the last 10 days $\left(R_{10 \mathrm{~d}}\right)$ is $30 \mathrm{~mm}$ or greater. Under these conditions fungicide spray is recommended. Days with minimum temperatures below $7.2^{\circ} \mathrm{C}$ are considered unfavorable.

Based on results presented by Fry et al. (1983), who considered $18-21^{\circ} \mathrm{C}$ as the optimum temperature range for potato late blight occurrence, and Garcia (2001) and Escalante \& Farrera (2004), who observed late blight occurrence under temperatures lower than $25^{\circ} \mathrm{C}$ in Venezuela, an adjustment was made in the temperature threshold of Hyre's model, considering days as favorable when $\mathrm{T}_{5 \mathrm{~d}}$ was below $22^{\circ} \mathrm{C}$. In addition to the procedure presented above, the following conditions were considered: pathogen was always present in the crop areas; there were no late blight resistant cultivars that meet commercial standards in Andes region of Venezuela; and each growing season ended when 1,500 DD (base temperature $=2^{\circ} \mathrm{C}$ ) had been accumulated or 140 days after emergence was reached.

\section{Data analysis}

The weather data obtained from 106 weather stations at Andes region, for a period of 31 years, were used to run Hyre's model for late blight occurrence on potato crop in a daily scale, according to the growing season of each place. This analysis, based on temperature and rainfall thresholds presented previously, resulted in the following variables: number of disease favorable days (DFD); number of periods with ten consecutive favorable days, named disease occurrence $(\mathrm{O})$; and number of sprays required for disease control (S), discounting the period of five days when the chemical control was effective after each spray. These variables were used to calculate the Maximum Risk Index (MRI, \%), obtained by the relationship between $\mathrm{S}$ and the maximum possible number of sprays, considering a 7-day interval, and the Probable Risk Index (PRI), which is the probable number of fungicide sprays, considering empirical probabilities of 25,50 , and $75 \%$. These fixed probabilities represent the chance of a given number of sprays to occur, like PRI $=7$ at $75 \%$ shows that 7 sprays are required for 75 of 100 years.
Maps of potato late blight MRI and PRI were obtained for 20 sowing dates (two per month), from $1^{\text {st }}$ January to $15^{\text {th }}$ October, which were grouped into three sowing seasons, as commonly adopted by growers of this region: from January to April (dry season); from May to July (rainy season); and from August to September (mid season). The interpolation of the disease risk indexes for each sowing season was done by geostatistics, using the ordinary Kriging method, according to the following steps: i) Assessment of the trend and the stationarity of both variables; ii) Establishment of experimental variograms with the software Variowin 2.2 - Vario2D (Pannatier, 1996); iii) Adjustment of experimental variograms to theoretical models with the software Variowin 2.2 Model (Pannatier, 1996); iv) Interpolation of both variables with the software TNTmips 6.7 (MicroImages, Inc.).

MRI and PRI data were submitted to an exploratory analysis to evaluate the shape of data distribution. A normal distribution was obtained for both. No trend was observed, confirming the hypothesis of stationary. The values of MRI and PRI for all growing seasons were also evaluated by variograms, using a spherical model, which showed that these variables were spatially auto-correlated, with a range of 50 to $60 \mathrm{~km}$ (Table 1). For MRI, the risks were categorized in four levels: low risk, when MRI ranged from 0 to $25 \%$; medium risk, when MRI ranged from 25.1 to $50 \%$; high risk, when MRI ranged from 50.1 to $75 \%$; and very high risk, when MRI ranged from 75.1 to $100 \%$.

\section{RESULTS}

\section{Climate of Andes region and potato late blight risk}

Although the three states are in the same region with similarities concerning the climate, some differences were observed (Figure 2). The average $T_{5 d}$ and $R_{10 d}$ of all weather stations of each state, together with temperature and rainfall thresholds for Hyre's model for potato late blight occurrence, show the main differences. In Táchira and Mérida states (Figures 2a and $2 \mathrm{~b}$ ), average $\mathrm{T}_{5 \mathrm{~d}}$ and $\mathrm{R}_{10 \mathrm{~d}}$ were always favorable for potato late blight from April to November $\left(\mathrm{T}_{5 \mathrm{~d}}<\right.$ $22^{\circ} \mathrm{C}$ and $\mathrm{R}_{10 \mathrm{~d}}>30 \mathrm{~mm}$ ), period that corresponds to the rainy and mid seasons. In these states, from December to March, the main limitation for late blight was the reduction in the rainfall. On the other hand, in Trujillo state the weather conditions for late blight, on average, were less favorable than the other two states, since $\mathrm{T}_{5 \mathrm{~d}}$ was always above $22^{\circ} \mathrm{C}$ and $\mathrm{R}_{10 \mathrm{~d}}$ stayed above $30 \mathrm{~mm}$ just during 80 days from March to June, and during another 80 days from September to November. 
Table 1 - Range, nugget effect, and sill for the spherical variogram model for maximum risk index (MRI) and probable risk index (PRI) for potato late blight in the states of Táchira, Mérida e Trujillo, in the Andes region of Venezuela.

\begin{tabular}{|c|c|c|c|c|}
\hline Growing Season & Probability Level & Range & Nugget Effect & Sill \\
\hline & & $\mathrm{km}$ & & \\
\hline Dry Season & - & 50.00 & 70.29 & 182.40 \\
\hline Rainy Season & - & 52.00 & 192.00 & 835.20 \\
\hline Mid Season & - & 54.52 & 128.92 & 402.97 \\
\hline Dry Season & 25 & 56.00 & 0.82 & 2.21 \\
\hline Dry Season & 50 & 60.00 & 0.74 & 1.60 \\
\hline Dry Season & 75 & 58.98 & 0.92 & 1.06 \\
\hline Rainy Season & 25 & 58.00 & 1.77 & 4.50 \\
\hline Rainy Season & 50 & 54.00 & 1.29 & 3.40 \\
\hline Rainy Season & 75 & 56.00 & 1.02 & 2.40 \\
\hline Mid Season & 25 & 53.38 & 0.55 & 2.76 \\
\hline Mid Season & 50 & 52.00 & 0.34 & 2.00 \\
\hline Mid Season & 75 & 53.38 & 0.22 & 1.07 \\
\hline
\end{tabular}
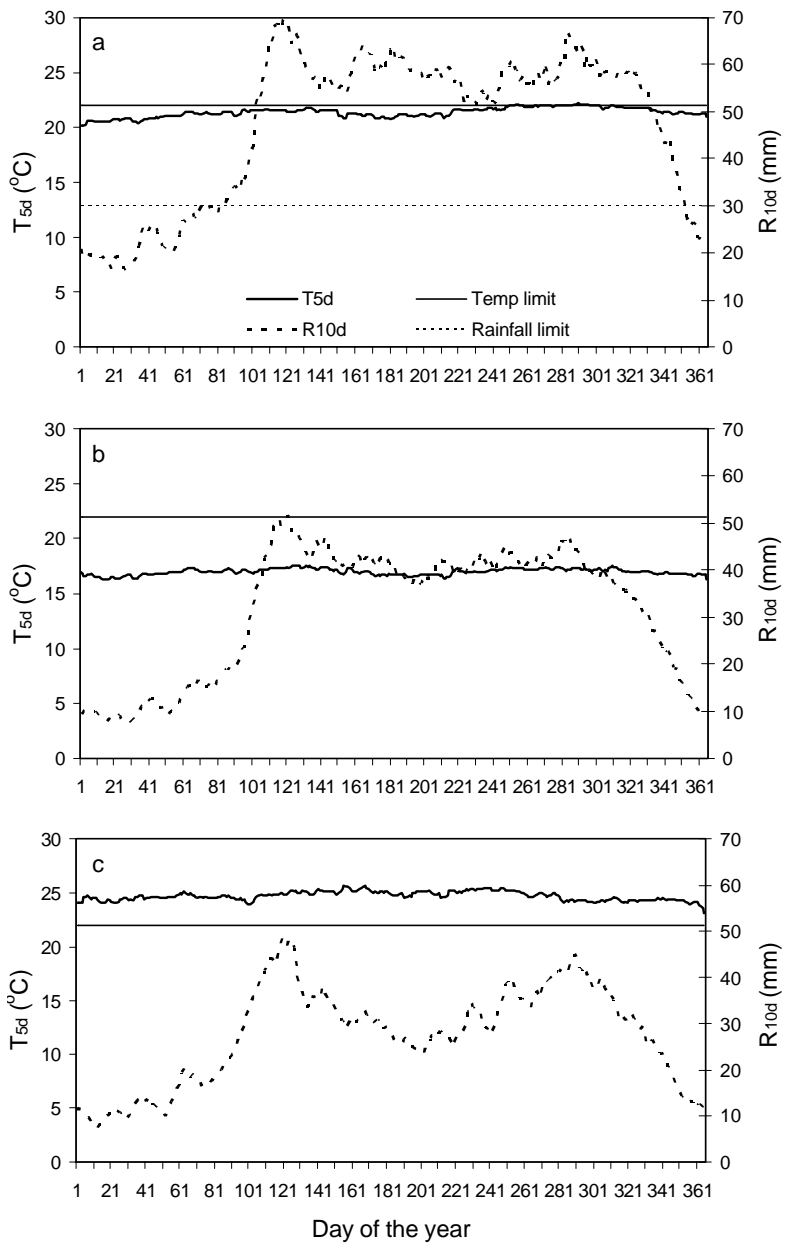

Figure 2 - Average weather conditions, from 1967 to 1996, represented by five-day average temperature $\left(\mathrm{T}_{5 \mathrm{~d}}\right)$ and total rainfall for the last ten days $\left(\mathrm{R}_{10 \mathrm{~d}}\right)$, for the states of Táchira (a), Mérida (b), and Trujillo (c), Venezuela. The horizontal lines are the thresholds (limits) considered by Hyre's model.
Even considering the importance of the average information for a first approach of the potential of potato late blight occurrence in Andes regions of Venezuela, this was not enough to characterize the potentialities of specific areas, since there is a high spatial variability of climatic conditions inside the studied states, especially because of the variation of altitude (from 0 to $5,000 \mathrm{~m}$ ). Figure 3 shows the variability of average DFD, $\mathrm{O}$ and $\mathrm{S}$ for each one of the 106 weather stations, taking into account an average of all simulated sowing dates. DFD ranged from one to more than 50 days in all states (Figure 3a), while $\mathrm{O}$ ranged from less than one to more than five (Figure $3 \mathrm{~b}$ ). The same variability was observed for $\mathrm{S}$, which represents better the late blight risk (Figure $3 \mathrm{c})$. In this case, the maximum average number of sprays predicted by Hyre's model was more than four, which was more frequent in Mérida State and less frequent in Trujillo.

\section{Maximum risk index}

The maps of MRI generated for each growing season are presented in Figure 4. For the dry season, which includes the sowing dates from January to April, MRI stayed around $25-30 \%$ in the majority of the areas where potato crop is cultivated in the three states, showing a low risk for late blight. In some few areas, however, MRI ranged from 50 to $60 \%$, representing a high risk. In general, MRI index shows the disease risk by the relationship between the number of sprays required and the number of sprays applied by a conventional control system (each seven days). In another way, this index also shows the percentage that can be avoided in relation to conventional control. During the dry season when the climate is less favorable for late 

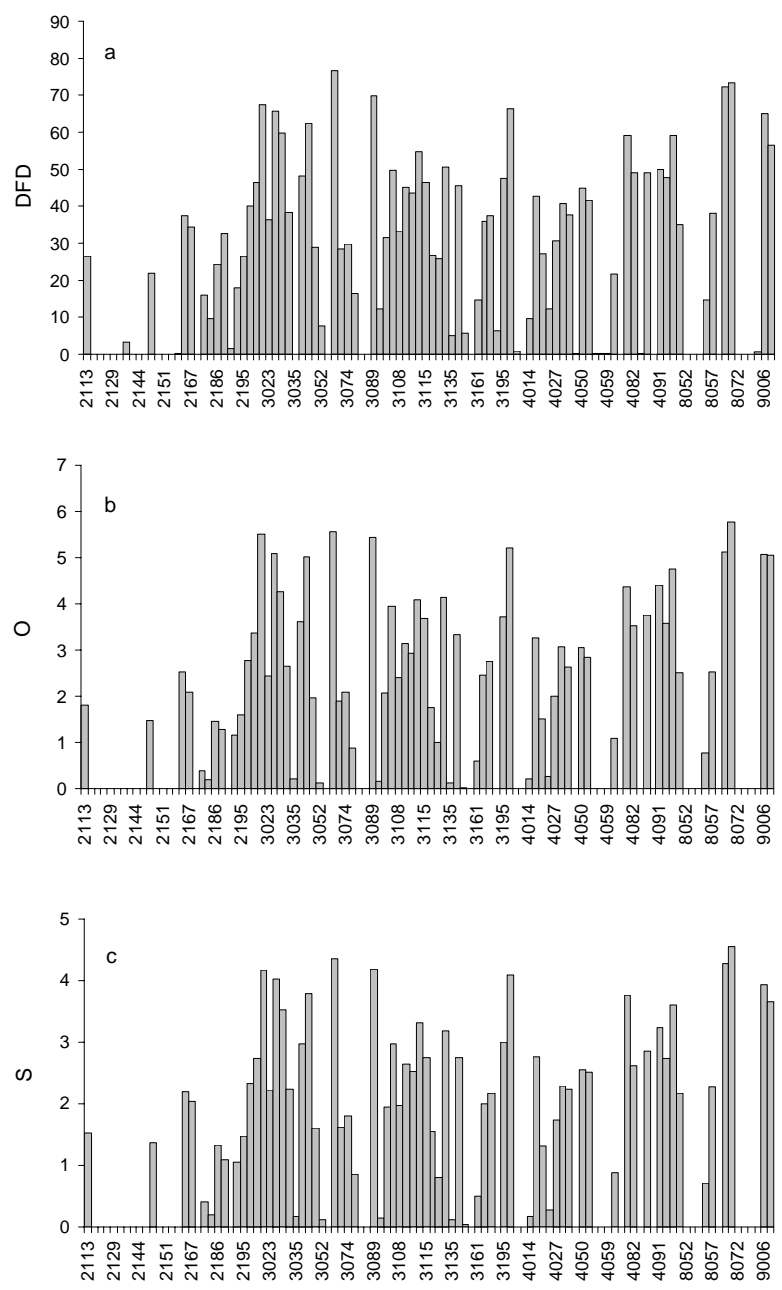

Weather Station

Figure 3 - Average values of: a) number of disease favorable days (DFD); b) number of periods with ten consecutive favorable days, named occurrence $(\mathrm{O})$; and c) number of sprays required for disease control (S), for each one of the weather stations, in Andes region of Venezuela. blight, sprays are necessary to control the disease but with 40 to $70 \%$ less applications than normally done by growers.

During the rainy season, from May to July, the risk for late blight increased since temperature and rainfall were within the limits required for disease development. During this season, MRI reached $100 \%$ in some places, but in the main potato production areas it ranged from 20 to $80 \%$. The most critical areas for late blight occurrence were in great part of Táchira state, south of Trujillo, and south and center of Merida state.

MRI decreased for the mid season, but still presenting medium to high risk (40-70\%) in some parts of Táchira state. In Mérida and Trujillo states MRI reached no more than $50 \%$ in some areas, which represents a medium risk for potato late blight. On average, for the majority of production areas of the Andes region, MRI during mid season was no greater than $30 \%$, what shows the high potential of a weatherbased disease warning system to help growers to reduce the number of sprays to control potato late blight.

In an overall perspective, dry and mid seasons are the best ones to grow potatoes in the Andes region of Venezuela, especially when sowing was performed from January to March (dry season) or in October (mid season). On the other hand, the worst period for potato sowing was from beginning of April to beginning of August, when rainfall amount was critical for late blight development.

\section{Probable risk index}

Another way to evaluate potato late blight risk was by considering the probability of its occurrence, represented by the number of sprays required in function of the weather conditions for each growing season and place. For that, the probable risk indexes for 25, 50 and $75 \%$ of probability were determined (Figures 5, 6, 7).

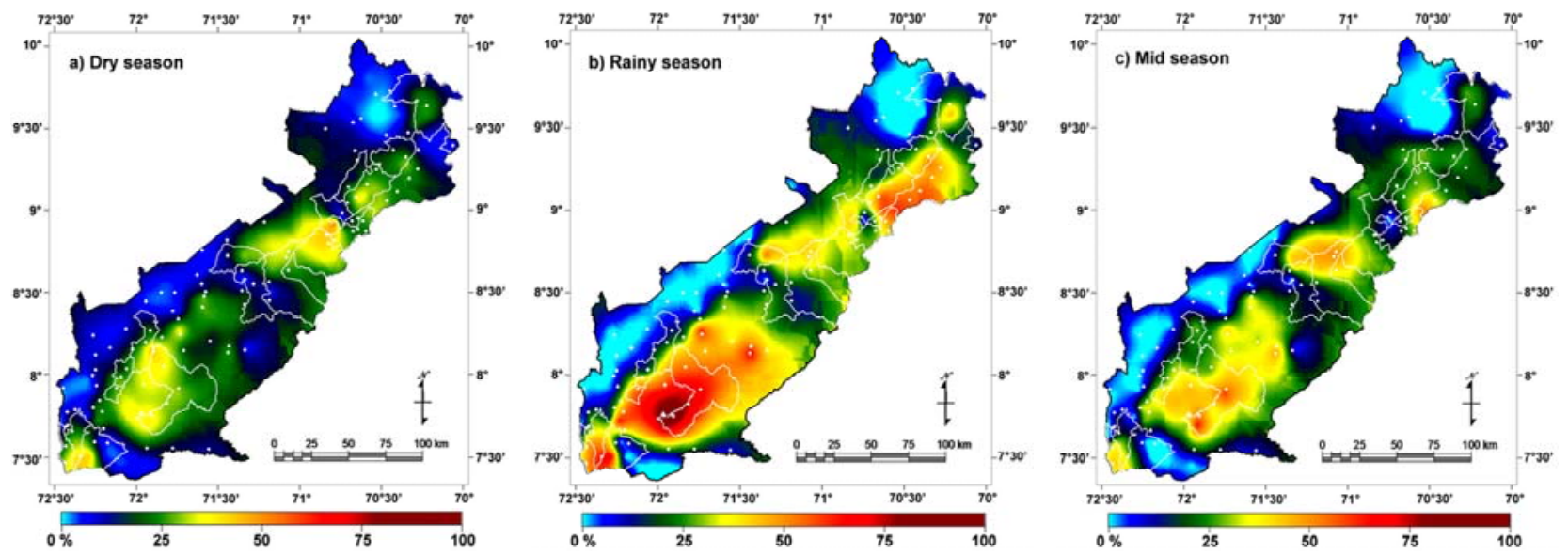

Figure 4 - Maps of maximum risk index (MRI) for potato late blight in the Andes region, Venezuela, for dry, rainy, and mid seasons.

Sci. Agric. (Piracicaba, Braz.), v.65, special issue, p.32-39, December 2008 

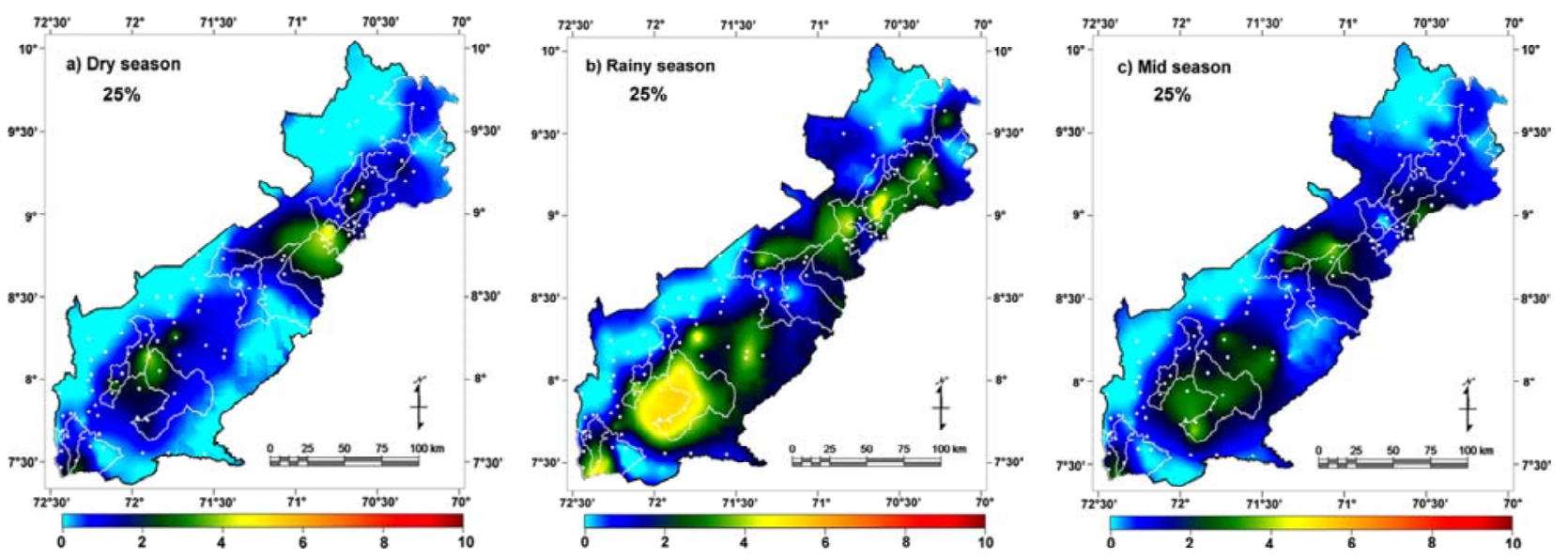

Figure 5 - Maps of probable risk index (PRI), at 25\% of probability, for potato late blight in Andes region, Venezuela, for dry, rainy, and mid seasons.
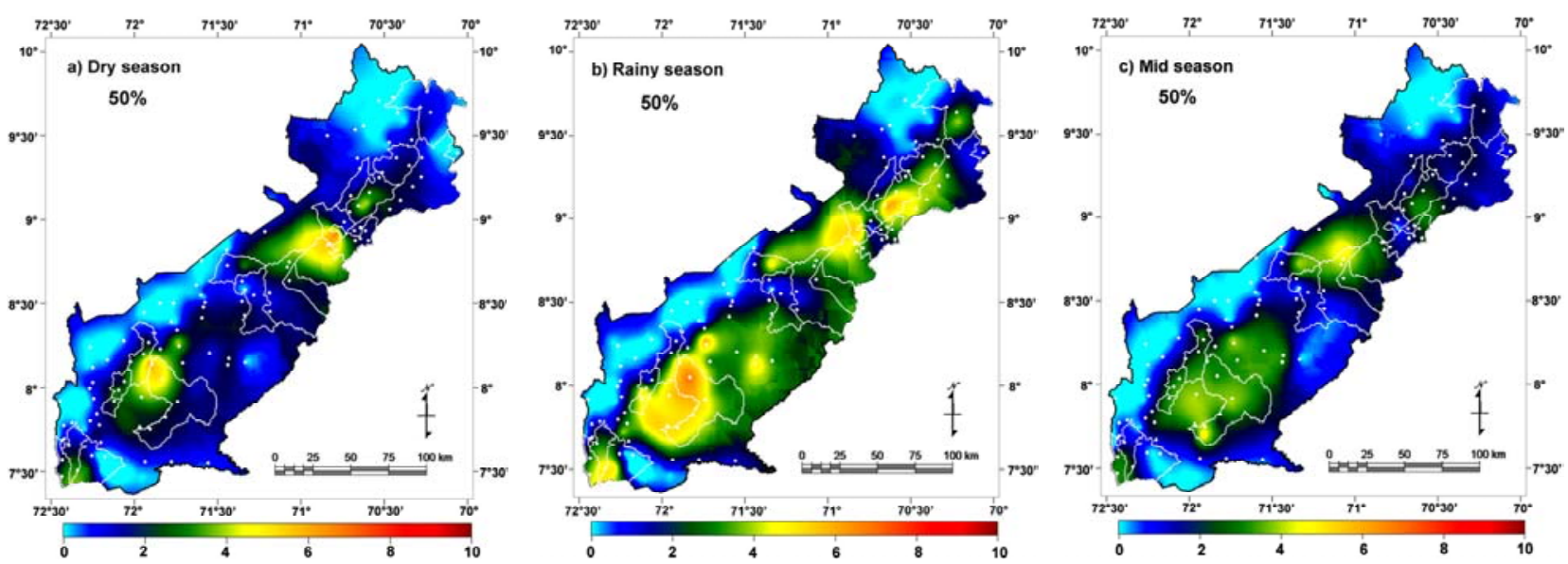

Figure 6 - Maps of probable risk index (PRI), at 50\% of probability, for potato late blight in Andes region, Venezuela, for dry, rainy, and mid seasons.

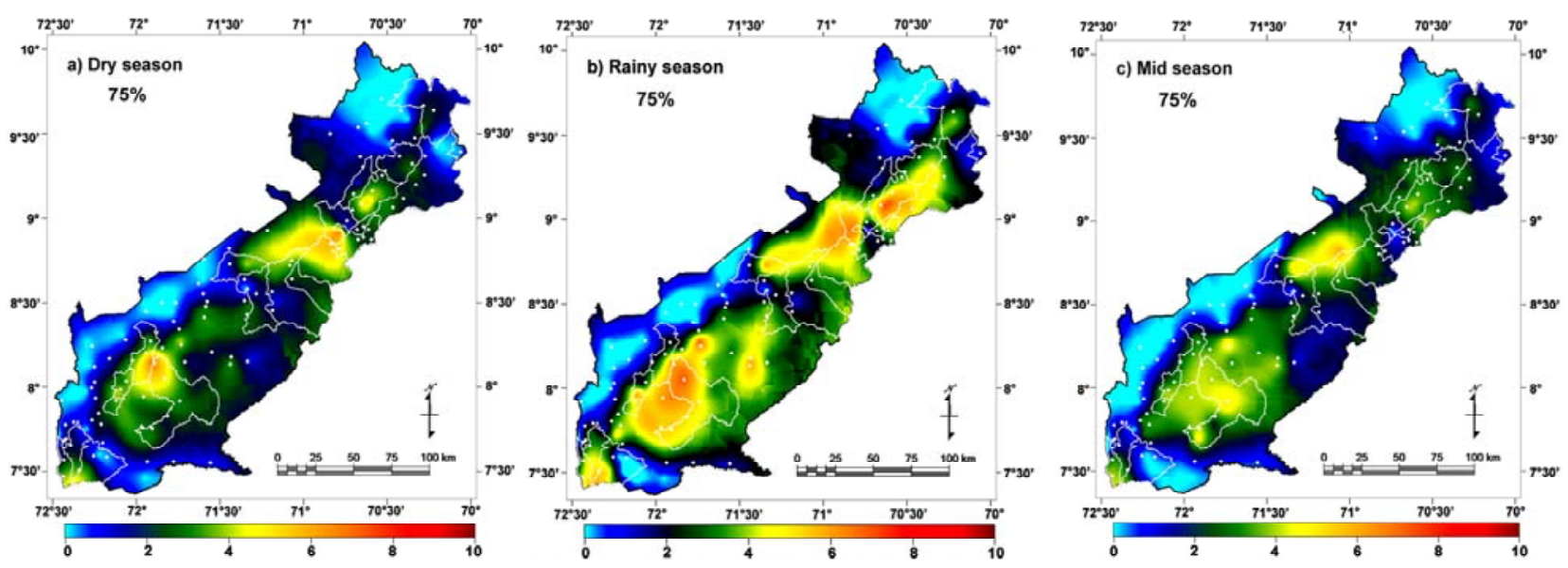

Figure 7 - Maps of probable risk index (PRI), at 75\% of probability, for potato late blight in Andes region, Venezuela, for dry, rainy, and mid seasons.

Sci. Agric. (Piracicaba, Braz.), v.65, special issue, p.32-39, December 2008 
At $25 \%$ of probability (Figure 5), the PRI values for dry and mid seasons were no greater than three sprays in the majority of the potato growing areas. However, during the rainy season, PRI increased mainly in Táchira state, achieving five sprays. This was also observed at few areas in the south of Trujillo. Considering now the probability of 50\% (Figure 6), PRI increased proportionally for all growing seasons, especially during the rainy one, when more than six sprays were required for many areas in Táchira. Finally, at $75 \%$ of probability (Figure 7), PRI ranged from one to five sprays in the dry season, achieving six or seven sprays in few areas at the north of Táchira and Mérida. In the rainy season, all the production areas required between three and seven sprays, while during mid season the requirement for late blight control was of three to five sprays.

\section{DISCUSSION}

The use of a GIS-linked weather-based disease model is an important contribution of geophytopathology to crop planning and rational control of diseases (Weltzien, 1972). In the present case, this procedure allowed obtaining reliable maps of potato late blight risk for Andes region of Venezuela. According to these maps, the disease risk varied among production areas in the same state, and among states and growing seasons. The state with the highest risk for potato late blight was Táchira, especially during the rainy season, when MRI can achieve $100 \%$ in some places. These results agree with those obtained by Hijmans et al. (2000), who considered, in an average global level, all the Andes region of Venezuela as of medium risk for potato late blight, using Simcast and Blitecast models. However, more details about late blight occurrence was observed in our study, since we identified disease risk variability in this region, what was not presented by Hijmans et al. (2000).

As fungicides are often used in excess and in high doses in the potato productions areas of Andes region, MRI values also showed that the number of sprays to control potato late blight in Andes region of Venezuela could be reduced when a weather-based disease model was used. Nazareno et al. (1999); Costa et al. (2002), and Taylor et al. (2003) have been presenting the valuable contribution of these systems for rationalizing potato late blight control. The possible reduction in the number of sprays, based on the Hyre's model, was more evident during dry and mid seasons and less during the rainy season. However, even during the rainy season fungicide applications could be reduced in relation to conventional control in the majority of potato areas. Reduction in the number of fungicides applications may be possible in seasons when meteorological con- ditions do not favor the disease for long periods of time (Taylor et al., 2003). Even considering the importance of this kind of information for establishing disease risk maps, these results are basically theoretical and must be considered with caution till Hyre's model and maps presented in our study could be validated for field conditions of Andes region of Venezuela.

The probable number of sprays, represented by PRI maps, is also important information for growers and governmental agencies. This is a useful information for crop planning and optimal disease control in an integrated disease management, since it indicates the probable number of sprays required for controlling late blight in a given region, contributing to rationalize fungicide use in potatoes. In our study, PRI ranged from one to five sprays in the dry season, achieving six or seven sprays in few areas at the north of Táchira and Mérida. In the rainy season, all the production areas required between three and seven sprays, while during mid season the requirement for late blight control was of three to five sprays. In all seasons, the number of sprays is much less than the conventional control, in which more than 15 sprays are commonly applied (International Potato Center, 2007). As already mentioned, these findings are just a theoretical approach that must be considered with caution. However, they provide a starting point for field experimentation, leading to more accurate results.

\section{CONCLUSIONS}

The highest climatic risk for potato late blight occurrence in the Andes region of Venezuela is during the rainy season, from May to July, decreasing during dry and mid seasons. However, high disease risk variability was observed for all seasons. In Táchira and Trujillo states disease risk was greater than in Mérida State. The maps generated by coupling an agrometeorological disease model and GIS showed to be a useful tool for crop planning and optimal disease management. Also, these maps showed that in great part of potato areas in Andes region would be possible to reduce the number of sprays, contributing to rationalize fungicide use, leading to less food and environment contamination, reduction of production costs, and safe conditions for field workers. Even considering the importance of the findings here presented, the results obtained are basically theoretical and must be considered with caution till their validation under field conditions.

\section{REFERENCES}

CALIFORNIA PESTCAST. Disease Model Database, 2007. Available at: http://www.ipm.ucdavis.edu/DISEASE/DATABASE/ potatolateblight.htm. Accessed 07 Feb. 2007. 
INTERNATIONAL POTATO CENTER. Potato: an opportunity for disease control. 2007. Available at: http://www.cipotato.org/ potato/pests_diseases/late_blight/ Accessed 12 Feb. 2007.

COSTA, R.V.; ZAMBOLIM, L.; VALE, F.X.R.; MIZUBUTI, E.S.G Previsão da requeima da batateira. Fitopatolologia Brasileira v.27, p.349-354, 2002.

ESCALANTE, O.M.; FARRERA, P.R. Epidemiologia del Tizón Tardio (Phytophthora infestans Mont de Bray) de la papa en zonas productoras del Estado Táchira, Venezuela. Bioagro, v.16, p.47-54, 2004.

FRY, W.E.; APPLE, A.E.; BRUHN, J.A. Evaluation of potato late blight forescasts modified to incorporate host resistence and fungicide weathering. Phytopathology, v.73, p.1054-1059, 1983.

GARCIA, R. La candelilla de la papa (Phytophthora infestans) en Venezuela. Perfil del país. Estado actual del manejo integrado del Tizón Tárdio (MIP-Tizón) en países Andinos. In: GILB LATIN AMERICA WORKSHOP, 1., Cochabamba, 2001. Proceedings. Cochabamba: GILB, 2001. p.41-45.

GARCIA, R.; GARCÍA, A. Evaluación de estrategías para el control químico del Tizón Tárdio de la papa en dos localidades del Estado Mérida, Venezuela. Bioagro, v.16, p.77-83, 2004.

GARRET, K.A.; DENDY, S.P. Cultural practices in potato late blight management. In: GILB LATIN AMERICA WORKSHOP, 1., Cochabamba, 2001. Proceedings. Cochabamba: GILB, 2001 p. 107-113.

HIJMANS, R.J.; FORBES, G.A.; WALKER, T.S. Estimating the global severity of potato Late Blight with a GIS-Linked Disease forecaster. Plant Pathology, v.49, p.697-705, 2000.

HYRE, R.A. Progress in forecasting late blight of potato and tomato. Plant Disease Reporter, v.38, p.245-253, 1954.

KANKWATSA, P.; HAKIZA, J.J.; OLANYA, M.; KIDENAMARIAM, H.M.; ADIPALA, E. Efficacy of different fungicide spray schedules for controlo $f$ potato late blight in southwestern Uganda. Crop Protection, v.22, p.545-552, 2003.
KIRK, W.W.; ABU-EL SAMEN, F.M.; MUHINYUZA, J.B.; HAMMERCHMIDT, R.; DOUCHES, D.S.; THILL, C.A.; GROZA, H.; THOMPSON, A.L. Evaluation of potato late blight management utilizing host plant resistance and reduced rates and frequencies of fungicide applications. Crop Protection, v.24, p.961-970, 2005.

LOZADA GARCIA, B.I. Risco climático de ocorrência da requeima da batata na região do Andes, Venezuela. Piracicaba: USP/ ESALQ, 2005. 132p. (Doutorado).

LOZADA GARCIA, B.I.; SENTELHAS, P.C.; TAPIA, L.; SPAROVEK, G. Filling in missing rainfall data in the Andes region of Venezuela, based on a cluster analysis approach. Revista Brasileira de Agrometeorologia, v.14, p.120-126, 2006.

NAZARENO, N.R.X.; SCOTTI, C.A.; MAFIOLETTI, R.L.; BOSCHETTO, N. Controle da requeima da batata através do monitoramento de variáveis climáticas. Fitopatologia Brasileira, v.24, p.170-174, 1999.

PANNATIER, Y. Variowin: software for spatial data analysis in 2D. New York: Springer, 1996. 91p.

TAYLOR, M.C.; HARDWICK, N.V.; BRADSHAW, N.J.; HALL, A.M. Relative performance of five forecasting schemes for potato late blight (Phytophtora infestans) I. Accuracy of infection warnings and reduction of unnecessary, theoretical, fungicide application. Crop Protection, v.22, p.275-283, 2003.

WELTZIEN, H.C. Geophytopathology. Annual Reviews, v.10, p.277-298, 1972.

Received November 01, 2007

Accepted April 11, 2008 